\title{
Constraining effect of mesoscale features on carbon budget of photic layer in the NE subtropical Atlantic
}

\author{
Beatriz Mouriño ${ }^{1,5, *}$, Emilio Fernández ${ }^{1}$, Robin Pingree $^{2}$, Bablu Sinha ${ }^{3}$, José Escánez ${ }^{4}$, \\ Demetrio de Armas ${ }^{4}$
}

\author{
${ }^{1}$ Universidade de Vigo, Departamento de Ecoloxía e Bioloxía Animal, Campus Lagoas-Marcosende, 36200 Vigo, Spain \\ ${ }^{2}$ The Laboratory, Marine Biological Association, Citadel Hill, Plymouth PL1 2PB, UK \\ ${ }^{3}$ Southampton Oceanography Centre, Southampton SO14 3ZH, UK \\ ${ }^{4}$ Instituto Español de Oceanografía, 38120 Santa Cruz de Tenerife, Spain
}

${ }^{5}$ Present address: Woods Hole Oceanographic Institution, Bigelow MS\# 9, Woods Hole, Massachusetts 02543, USA

\begin{abstract}
An oceanographic cruise was carried out in the subtropical NE Atlantic in April 1999 with the aim of investigating the role of the Azores Current, the STORM (subtropical oceanic rings of magnitude) cyclonic eddies and the Great Meteor Tablemount in triggering phytoplankton production. This information combined with previous studies allowed us to determine the role of these features in the carbon budget of the photic layer in this oligotrophic region. The results suggest that mesoscale dynamics, although modifying hydrographic characteristics and phytoplankton spatial distribution, do not appear to significantly affect primary production in the NE subtropical Atlantic.
\end{abstract}

KEY WORDS: Mesoscale features - Phytoplankton biomass - Primary production - Carbon budget · NE subtropical Atlantic

Resale or republication not permitted without written consent of the publisher

\section{INTRODUCTION}

Direct measurements of nutrient supply to oligotrophic surface waters have been considerably lower than indirect geochemical estimates in the NW subtropical Atlantic (Doney 1997). In the NE subtropical Atlantic, net heterotrophic behaviour has been observed repeatedly in the photic layer, resulting in an organic carbon deficit (Duarte et al. 2001, González et al. 2001, Serret et al. 2001, Teira et al. 2001). These observations could be the result of sampling strategies that tend to underestimate episodic nutrient inputs generated by events heterogeneous over temporal and/or spatial scales (Karl et al. 2003). In support of this hypothesis, several authors have proposed that mesoscale features could be an important vehicle for nutrient transport into the photic layers of open-ocean regions (see review by Garçon et al. 2001). However, enhanced biological activity associated with mesoscale dynamics is not persistent in time (Pelaez \&
McGowan, 1986, Sweeney et al. 2003, Mouriño et al. 2004), and recent modelling experiments disagree on the relevance of eddy-pumping in surface nitrate-depleted waters (Oschlies 2001, McGillicuddy et al. 2003). This disagreement could derive from the different temporal and spatial variability scales involved in the biological response associated with mesoscale dynamics, scales that modelling studies have not been able to completely reproduce so far.

Significant mesoscale activity has been widely reported for the NE subtropical Atlantic (e.g. Rogers 1994, Fernández \& Pingree 1996, Pingree et al. 1996, Garçon et al. 2001). However, this region is characterized by relatively low eddy energy levels compared with the NW subtropical Atlantic (Smith et al. 2000), where substantial evidence indicates that mesoscale eddies represent the main nutrient input mechanism into the euphotic layer (McGillicuddy et al. 1998, McNeil et al. 1999, Siegel et al. 1999). 


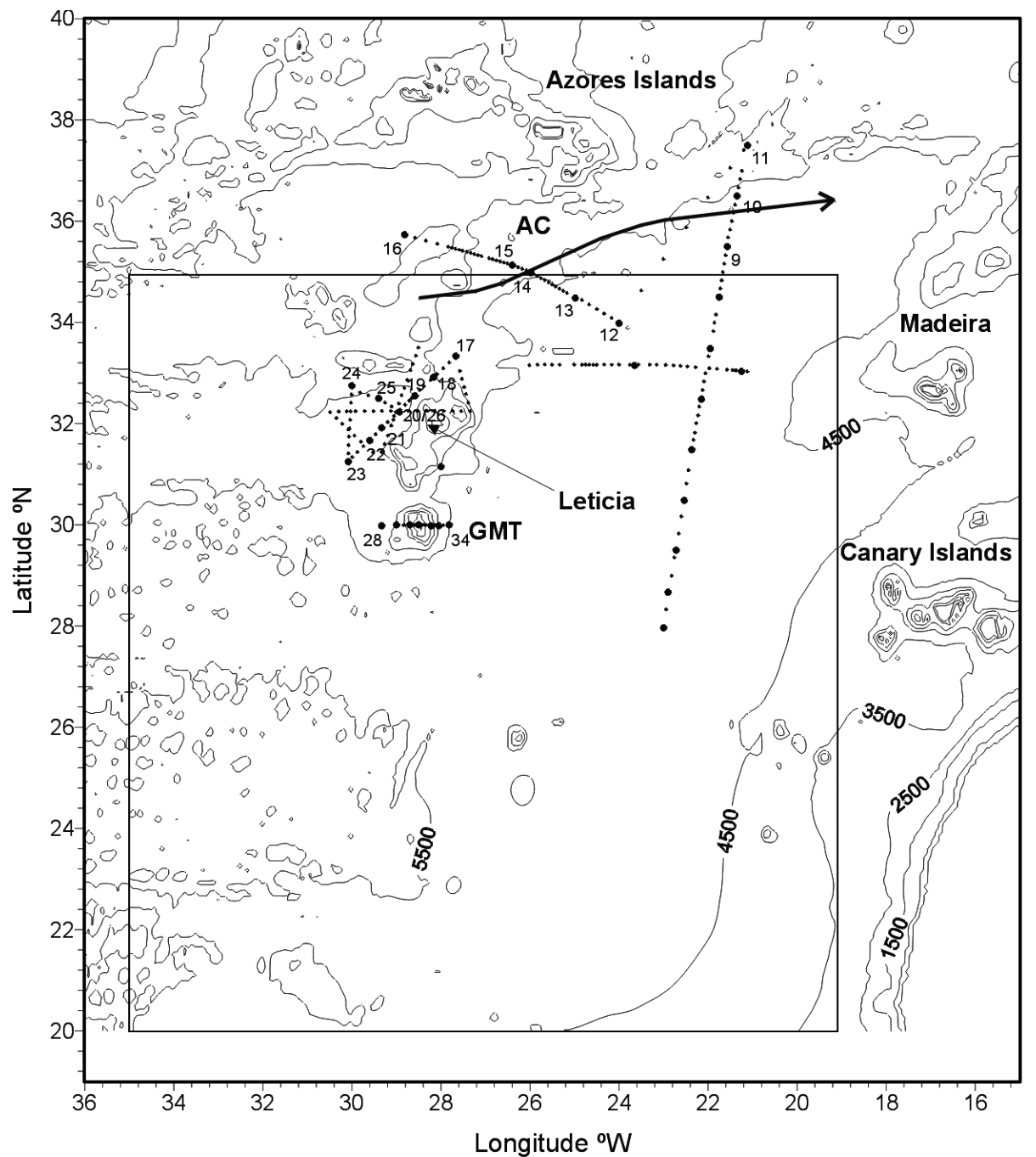

Fig. 1. 'Azores II' cruise track of the 'BIO Hespérides' in the NE Atlantic Ocean from Las Palmas (6 April 1999) to Cartagena (3 May 1999). (•) CTD stations (CTD number is indicated); (•) expendable bathythermographs; frame encloses eastern region of subtropical North Atlantic considered in this study $\left(20\right.$ to $35^{\circ} \mathrm{N}$, 19 to $35^{\circ} \mathrm{W}$ ); AC: Azores Current; Leticia: STORM eddy; GMT: Great Meteor Tablemount. Arrow indicates path of Azores Current
Representative mesoscale features of the NE subtropical Atlantic were studied during an oceanographic cruise in April 1999. This data was combined with that of previous studies in the region to determine the role of mesoscale dynamics in the carbon budget of the photic layer and to explore the possibility of regional differences in the relevance of eddy-pumping in oligotrophic ecosystems.

\section{MATERIALS AND METHODS}

We studied 36 stations in the NE subtropical Atlantic during the 'Azores II' cruise on board the 'BIO Hespérides'. The data obtained allowed us to investigate the physical structure and the potential enhancement of phytoplankton production and biomass of the Azores Current/Subtropical Front system (AC/STF) (Gould 1985), large cyclonic eddies budded from the Azores Current (STORMS; subtropical oceanic rings of magni- tude: Pingree et al. 1996) and hydrographic features associated with the Great Meteor Tablemount (GMT). The cruise track (Fig. 1) was decided on a daily basis according to the information derived from expandable bathythermographs (XBT), conductivity temperature depth (CTD) data, and the operational ocean mesoscale forecasting system SOPRANE (Systeme Océanique de Prévision Régionale en Atlantique Nord-Est; see Mouriño et al. 2003). Firstly, 2 sections (Stn 1 to 11 and Stn 12 to 16) crossed the meandering region of the $\mathrm{AC/STF}$ system, then intensive sampling was conducted in the region centred at $32.4^{\circ} \mathrm{N}$ to $28.7^{\circ} \mathrm{W}$, where a $\sim 20 \mathrm{~cm}$ sea-level depression had been previously detected by SOPRANE. This sea-level depression was related to a STORM eddy called 'Leticia'. Finally, the 'Hespérides' steamed south towards $30^{\circ} \mathrm{N}$ and crossed the GMT. Surface temperature and salinity were continuously monitored by means of a SBE-21 thermosalinograph. CTD profiles were conducted with a Neil Brown Mark III probe attached to a 

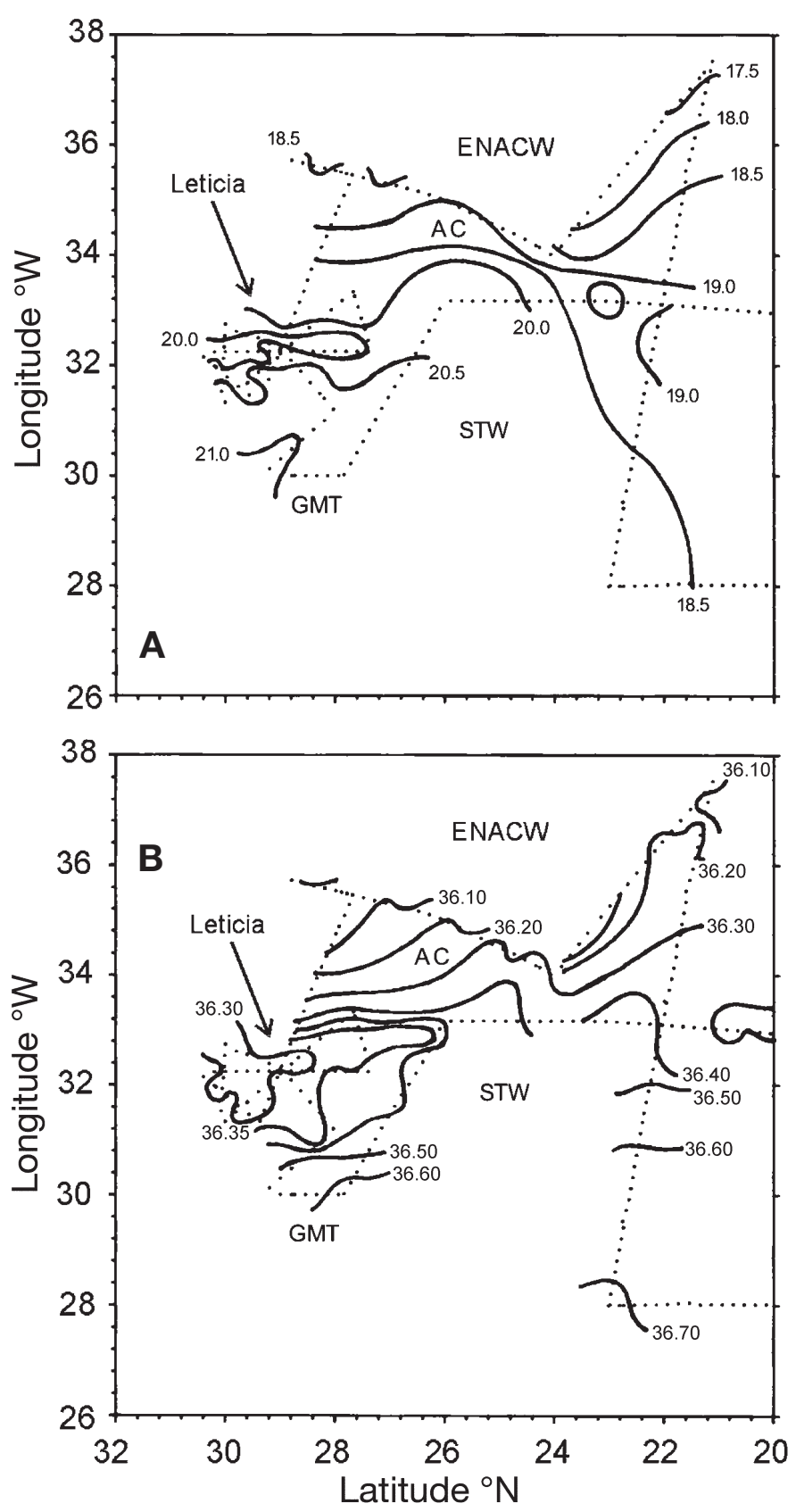

Fig. 2. (A) Surface temperature and (B) salinity in the eastern part of the North Atlantic in April 1999 during the 'Azores II' cruise. Dotted lines: interpolated $\left(0.2^{\circ}\right.$ interval $)$ positions considered for the thermosalinograph data; ENACW: Eastern North Atlantic Central Water; STW: Subtropical Water; other labelling as in Fig. 1

rosette equipped with 101 Niskin bottles. Samples were collected on each CTD cast for the determination of dissolved inorganic nitrogen, dissolved oxygen and chlorophyll a concentrations. At selected stations, carbon incorporation rates by phytoplankton were determined by on-deck incubations cooled by surface waters for 7 to $11 \mathrm{~h}$ (see details in Mouriño et al. 2002).

\section{RESULTS AND DISCUSSION}

The surface thermohaline characteristics of the region in April 1999 are shown in Fig. 2. The position of the AC (about $34^{\circ} \mathrm{N}$ ) was associated with a marked gradient in surface temperature and salinity $\left(\sim 2^{\circ} \mathrm{C}\right.$ and $0.3 \mathrm{psu}$, respectively) at the frontal boundary between the Eastern North Atlantic Central Water (ENACW) and Subtropical Water (STW) on the northern and southern side of the $\mathrm{AC}$, respectively (Pingree et al. 1996, New et al. 2001). A central core of relatively cold $\left(<20^{\circ} \mathrm{C}\right)$ and less saline $(<36.2 \mathrm{psu})$ water was the main surface signature of the cyclonic eddy 'Leticia'. No surface thermohaline anomalies were associated with the GMT.

Fig. 3 shows the vertical distribution of sigma-0, geostrophic velocity $\left(\mathrm{cm} \mathrm{s}^{-1}\right)$, nitrate $(\mu \mathrm{M})$ and chlorophyll a $\left(\mathrm{mg} \mathrm{m}^{-3}\right)$ across (A) the AC/STF system, (B) 'Leticia' and (C) the GMT. Isopycnals outcropped at $35.0^{\circ} \mathrm{N}$ defining the position of the STF. Geostrophic velocities showed the close association between the STF and the AC, with maximum values $\left(\sim 14 \mathrm{~cm} \mathrm{~s}^{-1}\right)$ in the upper $25 \mathrm{~m}$. A sharp nitrate gradient was associated with the STF. Differences in nitrate concentration between the northern and southern side of the STF at 100 and 200 dbar were 1.54 and $6.68 \mu \mathrm{M}$, respectively. Chlorophyll a concentration showed a distinct and continuous subsurface maximum at about 75 dbar that was slightly shallower and of higher magnitude $\left(>0.3 \mathrm{mg} \mathrm{m}^{-3}\right)$ at the STF.

The vertical hydrographic structure across 'Leticia' showed an upward displacement of isopycnals of more than $100 \mathrm{~m}$ over horizontal scales of ca. $100 \mathrm{~km}$ (Fig. 3B). The STORM eddy rotated cyclonically, with maximum geostrophic velocities in the upper $200 \mathrm{~m}$ $>25 \mathrm{~cm} \mathrm{~s}^{-1}$. Nitrate concentrations were lower than $0.5 \mu \mathrm{M}$ at $100 \mathrm{~m}$, except at Stns 19 and 22, where 1.76 and $0.84 \mu \mathrm{M}$ were measured at this depth, respectively. The deep chlorophyll maximum (DCM) was located at ca. $100 \mathrm{~m}$, except at the eddy centre, where it was located shallower (ca. $50 \mathrm{~m}$ ). Maximum concentrations (>0.3 $\mathrm{mg} \mathrm{m}^{-3}$ ) were measured at Stn 19 (inside the eddy) and at Stn 17 (outside the eddy).

Isopycnals outcropped over the GMT slope (Fig. 3C). Geostrophic velocities calculated across the GMT revealed the existence of a southward current of $>15 \mathrm{~cm}$ $\mathrm{s}^{-1}$ in the upper 200 dbar of the western flank of the seamount. Surface waters were nitrate depleted, with concentrations $<0.5 \mu \mathrm{M}$ in the upper $90 \mathrm{~m}$, except at Stns 30 and 31 , where 0.67 and $0.77 \mu \mathrm{M}$ were measured at this depth, respectively. Maximum chlorophyll a (chl a) values at the DCM $\left(>0.3 \mathrm{mg} \mathrm{m}^{-3}\right)$ were observed over the seamount slope.

Fig. 4 shows the vertical distribution of chemical and biological properties at stations located within the 

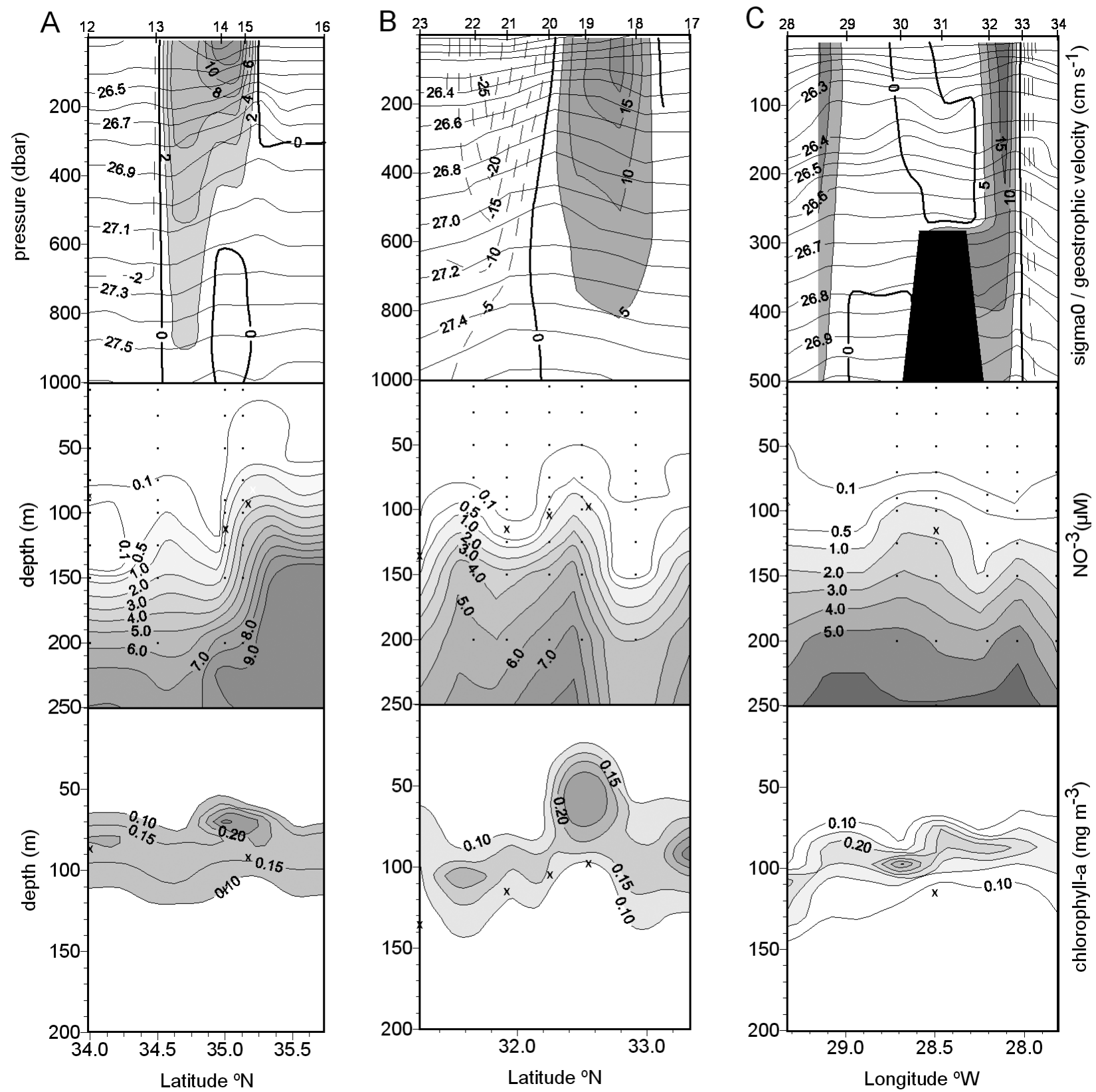

Fig. 3. Vertical distribution of sigma-0, geostrophic velocity relative to $2000 \mathrm{~m}$, nitrate and chlorophyll a concentration across (A) the Subtropical Front, (B) the cyclonic eddy 'Leticia' and (C) the Great Meteor Tablemount. (X) photic layer depth (1\% surface irradiance). Numbers on the top axis represent Station numbers

mesoscale features investigated in this study and in STW not affected by these mesoscale structures. Averaged nitrate profiles showed uplifting of the nutricline $(0.5 \mu \mathrm{M}$, ca. $30 \mathrm{~m}$ ) associated with the mesoscale features compared to STW. Although local enhancements of chl a concentrations were found associated with some stations located within the mesoscale features (a chl a maximum of $0.75 \mathrm{mg} \mathrm{m}^{-3}$ was measured in GMT versus a maximum of $0.23 \mathrm{mg} \mathrm{m}^{-3}$ in STW), the maximum primary production rate was measured in STW $\left(0.31 \mathrm{mg} \mathrm{C} \mathrm{m}^{-3} \mathrm{~h}^{-1}\right)$, and averaged profiles did not show noticeable phyto- plankton biomass and production increases associated with the mesoscale features. No noteworthy significant differences were found in the contribution of small-sized phytoplankton $(<2 \mu \mathrm{m})$ to total chl $a$, their contribution to carbon incorporation rates being slightly higher within mesoscale features. Small differences in chl a values between the vertical sections (Fig. 3) and vertical profiles (Fig. 4) derive from the different data sets used for both representations (calibrated fluorescence from CTD in Fig. 3 and extracted size-fractionated chl $a$ in Fig. 4: see Mouriño et al. 2002). 

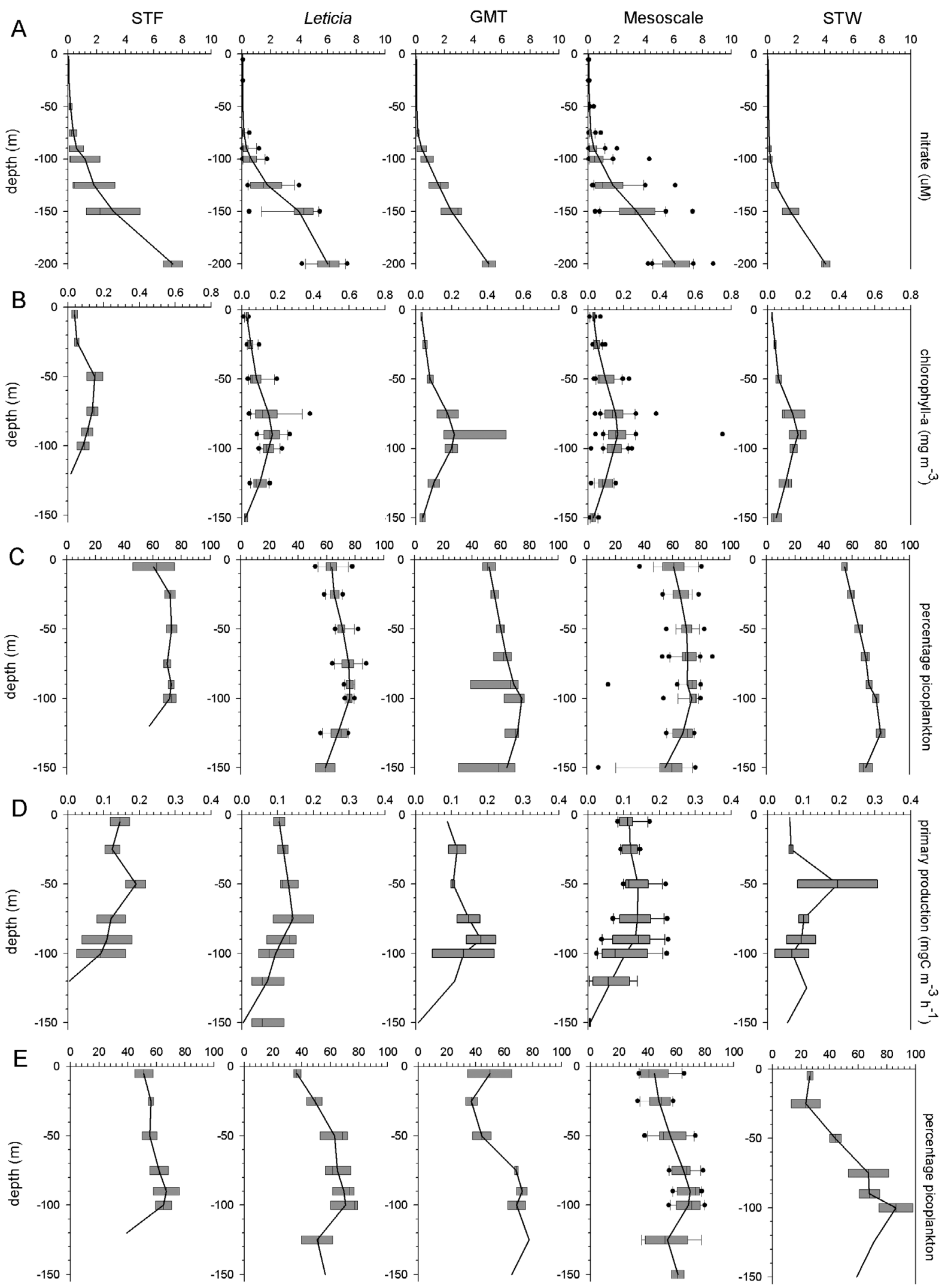

Fig. 4. Box-and-whisker plots of (A) nitrate concentration; (B) chlorophyll a concentration; (C) contribution of small-sized phytoplankton $(<2 \mu \mathrm{m})$ to total chlorophyll $a_{i}$ (D) carbon incorporation rates (primary production); and (E) contribution of small-sized phytoplankton $(<2 \mu \mathrm{m})$ to total primary production at stations in the Subtropical Front (STF; Stns 9, 10, 14, 15), 'Leticia' (L, Stns 18, 19, 20/26, 21, 22, 24, 25), the Great Meteor Tablemount (GMT; Stns 30, 31, 32, 33), mesoscale features (STF, L, GMT) and Subtropical Waters (STW; Stns 23, 28, 34). Boxes represent $50 \%$ of data, and whiskers 10th and 90th percentiles; continuous lines: average profiles. As samples were collected at different depths, linear interpolated values were used for analysis 
Table 1. Averaged $( \pm \mathrm{SE})$ values of selected physical, chemical and biological variables at stations in the Subtropical Front $(\mathrm{STF} ;$ Stns 9, 10, 14, 15), 'Leticia' (Li Stns 18, 19, 20/26, 21, 22, 24, 25), the Great Meteor Tablemount (GMT; Stns 30, 31, 32, 33), mesoscale features (STF, L, GMT) and Subtropical Waters (STW; Stns 23, 28, 34); $150 \mathrm{~m}$ integration depth represents the level where primary production rates were closer to 0 . $n$ : number of stations

\begin{tabular}{|c|c|c|c|c|c|c|c|c|c|c|c|c|c|c|c|}
\hline \multirow{2}{*}{ Variables } & \multicolumn{3}{|c|}{ STF } & \multicolumn{3}{|c|}{ Leticia } & \multicolumn{3}{|c|}{ GMT } & \multicolumn{3}{|c|}{ Mesoscale features } & \multicolumn{3}{|c|}{ STW } \\
\hline & Mean & $\mathrm{SE}$ & $\mathrm{n}$ & Mean & $\mathrm{SE}$ & $\mathrm{n}$ & Mean & $\mathrm{SE}$ & $\mathrm{n}$ & Mean & $\mathrm{SE}$ & $\mathrm{n}$ & Mean & $\mathrm{SE}$ & $\mathrm{n}$ \\
\hline Depth $16^{\circ} \mathrm{C}$ isotherm & 170 & 25 & 4 & 228 & 20 & 7 & 278 & 5 & 4 & 226 & 15 & 15 & 315 & 18 & 3 \\
\hline $\begin{array}{l}\text { Photic layer-integrated nitrate } \\
\text { concentration }\left(\mathrm{mmol} \mathrm{m}^{-2}\right)\end{array}$ & 24 & 14 & 3 & 22 & 14 & 4 & 41 & - & 1 & 25 & 8 & 8 & 10 & - & 1 \\
\hline $\begin{array}{l}\text { Depth }(0-150 \mathrm{~m}) \text {-integrated } \\
\text { chlorophyll a }\left(\mathrm{mg} \mathrm{m}^{-2}\right)\end{array}$ & 15 & 1 & 4 & 13 & 1 & 7 & 13 & 1 & 4 & 14 & 1 & 15 & 12 & 2 & 3 \\
\hline $\begin{array}{l}\text { Percentage picoplankton, } 0-150 \mathrm{~m} \\
(<2 \mu \mathrm{m}) \text { chlorophyll } a\end{array}$ & 68 & 4 & 4 & 73 & 1 & 7 & 59 & 10 & 4 & 68 & 3 & 15 & 73 & 1 & 3 \\
\hline $\begin{array}{l}\text { Depth }(0-150 \mathrm{~m}) \text {-integrated primary } \\
\text { production }\left(\mathrm{mg} \mathrm{C} \mathrm{m}^{-2} \mathrm{~d}^{-1}\right)\end{array}$ & 156 & 44 & 2 & 151 & 36 & 3 & 166 & 52 & 2 & 156 & 17 & 7 & 141 & 13 & 2 \\
\hline $\begin{array}{l}\text { Percentage picoplankton, } 0-150 \mathrm{~m} \\
(<2 \mu \mathrm{m}) \text { primary production }\end{array}$ & 55 & 6 & 2 & 61 & 5 & 3 & 59 & 9 & 2 & 59 & 3 & 7 & 54 & 3 & 2 \\
\hline
\end{tabular}

Similar results were obtained when integrated values were compared (Table 1). A more than 2-fold increase in photic depth-integrated nitrate concentration was found associated with the mesoscale features compared to STW. Local increments in phytoplankton biomass and primary production rates were associated with some stations located within the AC/STF system, 'Leticia' and GMT. However, averaged depth-integrated chl $a$ and carbon incorporation rates measured at STW $\left(12 \pm 2 \mathrm{mg} \mathrm{chl} \mathrm{a} \mathrm{m}{ }^{-2}, 141 \pm 13 \mathrm{mg} \mathrm{C} \mathrm{m}^{-2} \mathrm{~d}^{-1}\right)$ did not differ significantly ( $p=0.42$ and $p=0.62$, respectively) from the values obtained in water bodies affected by mesoscale features $\left(14 \pm 1 \mathrm{mg} \mathrm{chl} \mathrm{a} \mathrm{m}{ }^{-2}, 156 \pm 17 \mathrm{mgC}\right.$ $\left.\mathrm{m}^{-2} \mathrm{~d}^{-1}\right)$. Primary production data measured during the 'Azores II' cruise compare well with the rates measured in the region in April $2001\left(\sim 150 \mathrm{mg} \mathrm{C} \mathrm{m}^{-2} \mathrm{~d}^{-1}\right.$, Mouriño: 2002). No statistically significant differences $(p=0.43$ and $\mathrm{p}=0.39$, respectively) were found in the contribution of small-sized phytoplankton $(<2 \mu \mathrm{m})$ to total chl a and carbon incorporation rates between STW (73 and $54 \%$, respectively) and mesoscale features (68 and $59 \%$, respectively).

The results presented in this study show that the AC/STF system, the STORM eddies and the GMT, although modifying hydrographic characteristics of the water column, did not significantly affect photic layer productivity in April 1999. We are well aware that this result cannot be extrapolated over the entire seasonal cycle. However, indirect estimates allow us to determine the magnitude of the effect of these mesoscale features on the total amount of photosynthetic carbon produced in the subtropical NE Atlantic, suggesting that this effect is likely to be small.

A previous study conducted in the GMT by Mouriño et al. (2001) showed the existence of local increases in chl a-enhanced carbon-incorporation rates and changes in phytoplankton species composition associ- ated with the seamount. These effects were, nevertheless, subject to a large degree of temporal and spatial variability both at seasonal and shorter time scales. In order to estimate an upper threshold for the significance of seamounts on the primary productivity of the region, we used for our calculations the highest primary production rate measured over the GMT by Mouriño et al. (2001) (441 $\mathrm{mg} \mathrm{C} \mathrm{m}^{-2} \mathrm{~d}^{-1}$ ). Using this rate and considering the spatial extension of submarine banks rising from the ocean bottom to depths shallower than $500 \mathrm{~m}(<1 \%$ of the region, see Fig. 1, and htpp://topex.ucsd.edu/marine_topo/mar_topo.html), i.e. those expected to modify the hydrographic characteristics of the photic layer, we estimated that the maximum net primary production associated with the

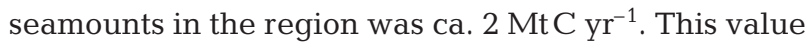
represents a $<1 \%$ increase over the net primary production of the region, calculated assuming a surface area for the whole NE Atlantic subtropical region of $2.6 \times 10^{12} \mathrm{~m}^{2}$ (see Fig. 1) and the averaged net primary production rate reported by Marañón et al. (2003) $\left(264 \pm 69 \mathrm{mg} \mathrm{C} \mathrm{m}^{-2} \mathrm{~d}^{-1}\right)$ for this region.

Chl a concentrations and primary production rates measured in the AC/STF region in April 1999 were considerably lower than those in March 1992, when 2 distinct and isolated chlorophyll patches were identified related to the boundaries of the STF, and chl a values, and carbon incorporation rates were 2 to 3 higher at the frontal boundary than in surrounding waters not affected by mesoscale features (Fernández \& Pingree 1996). We first assumed that the maximum primary production rate measured at the STF in March 1992 (1056 $\mathrm{mgC} \mathrm{m}^{-2} \mathrm{~d}^{-1}$ ) remained constant over a 2 mo period. This agrees well with the period when maximum surface chl a concentration (see Fig. 17 of Pingree et al. 1999) and primary production rates (Longhurst 1995) are observed or modelled in the region, but 
probably overestimates the duration of the episodic event investigated in March 1992. We further assumed a surface area for the STF of $2.5 \times 10^{11} \mathrm{~m}^{2}$, calculated considering the STF as a band of $\sim 160 \mathrm{~km}$ width from 19 to $35^{\circ} \mathrm{W}$ (Fernández \& Pingree 1996). The maximum net primary production associated with the STF

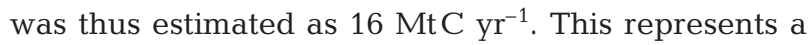
$5 \%$ increase over the annual net primary production estimated for the whole NE Atlantic subtropical region.

Primary production rates measured in the eddy 'Leticia' were lower than the average net primary production rate reported for the region by Marañón et al. (2003). 'Leticia' was probably in the decaying stage of development (Mouriño et al. 2002), and as a consequence, primary production rates measured within this eddy are likely to be at the lower end of the range of variability characteristic of STORM eddies. Assuming a 4 -fold increase in the primary production rate characteristic of STORM eddies (a value considerably higher than the maximum phytoplankton carbon incorporation rate measured in the region: $\sim 350 \mathrm{mgC}$ $\mathrm{m}^{-2} \mathrm{~d}^{-1}$; Marañón et al. 2003), and considering the mean surface area and lifetime of STORM eddies (estimated by an automatic system for eddy tracking through the 1993 to 1999 period; Mouriño et al. 2003), we estimated that the variability in the annual net primary production associated with STORM eddies

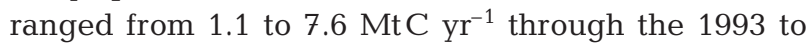
1999 period. This represents a $<2 \%$ increase in the total net primary production of the region.

The estimates presented in this study indicate that the potential enhancement of primary production rates associated with the mesoscale features investigated herein may be responsible of $<7 \%$ increase in the total net primary production of the region. However, even small increases in primary production levels might be of relevance in terms of carbon export if the magnitude of the $f$-ratio were affected. In this respect, a recent study on the biochemical impacts of mesoscale activity in the Sargasso Sea reported higher rates of vertical particle flux and shifts in the size distribution of the phytoplankton community towards larger species associated with the passage of mesoscale eddies (Sweeney et al. 2003). Unfortunately, information on the potential capacity for carbon export in the mesoscale features investigated in this study is scanty and limited to a few observations. Thus, respiration rates measured in 'Leticia' in April 1999 were significantly lower inside than outside the eddy, and hence, in contrast to the net heterotrophic metabolism measured in the NE subtropical Atlantic, 'Leticia' data showed a net autotrophic microbial $\mathrm{O}_{2}$ balance (González et al. 2001).

According to the empirical model developed by Serret et al. (2002) to predict the net metabolism of the planktonic community from carbon incorporation rates measured in the NE Atlantic Ocean, a $<7 \%$ increase in total net primary production would mean $<10 \%$ reduction in the organic matter deficit estimated for this region (388 $\mathrm{mg} \mathrm{C} \mathrm{m}^{-2} \mathrm{~d}^{-1}$ : Serret et al. 2002). Although any attempt to quantitatively estimate the increase in net community production (NCP) rates associated with the mesoscale features from $\mathrm{PO}^{14} \mathrm{CP}$ data would probably not yield reliable results, the fact that (1) mesoscale features are not always associated with enhanced biological activity (as observed in April 1999) and (2) the combined effect of the 3 mesoscale regimes investigated in this study on the whole area is relatively small indicates that the magnitude of the expected increase in NCP is likely to be very small or in any case irrelevant compared to the organic matter deficit estimated for the region. In conclusion, although the mesoscale structures investigated in the NE subtropical Atlantic in April 1999 significantly modify phytoplankton spatial distribution, their contribution to the carbon budget of the photic layer in the region appears to be limited. This contrasts with results obtained for the dynamic NW subtropical Atlantic and points to regional differences in the role of eddy pumping in subtropical regions.

Acknowledgements. M. J. Pazó and E. Teira (Universidade de Vigo) provided the chlorophyll a and primary production data. We thank the Collecte Localisation Satellites for SOPRANE images received on board the 'BIO Hesperides'. B. Mouriño thanks S. Anderson (Southampton Oceanographic Centre) for support with the pstar program. We wish to thank the crew of the 'BIO Hesperides' and UGBO personnel for their valuable support at sea and excellent technical support. Constructive comments by 4 anonymous reviewers notably improved an earlier version of the manuscript. This study was funded by the European Commission and the Spanish Ministerio de Educación y Cultura through the research programmes CANIGO (MAS3CT960060) and CARPOS (REN2003-09532-C03-01). B. Mouriño was supported by a PFPU fellowship from the Ministerio de Educación y Cultura (MEC, Spain) and a MECD/Fulbright postdoctoral fellowship.

\section{LITERATURE CITED}

Doney SC (1997) The ocean's productive deserts. Nature 389:905-906

Duarte CM, Agustí S, Arístegui J, González N, Anadón R (2001) Evidence for a heterotrophic subtropical northeast Atlantic. Limnol Oceanogr 46:425-428

Fernández E, Pingree RD (1996) Coupling between physical and biological fields in the North Atlantic subtropical front southeast of the Azores. Deep-Sea Res I 43:1369-1393

Garçon VC, Oschlies A, Doney SC, McGillicuddy D, Waniek J (2001) The role of mesoscale variability on plankton dynamics in the North Atlantic. Deep-Sea Res II 48:2199-2226

González N, Anadón R, Mouriño B, Fernández E, Sinha B, Escánez J, de Armas D (2001) The metabolic balance of the planktonic community in the N. Atlantic Subtropical Gyre: the role of mesoscale instabilities. Limnol Oceanogr 46:946-952 
Gould WJ (1985) Physical oceanography of the Azores Front. Progr Oceanogr 14:167-190

Karl DM, Laws E, Morris P, Williams PJ, Emerson S (2003) Metabolic balance of the open ocean. Nature 426:32

Longhurst AR (1995) Seasonal cycles of pelagic production and consumption. Prog Oceanogr 36:77-167

Marañón E, Behrenfeld M, González N, Mouriño B, Zubkov MV (2003) High variability of primary production in the Atlantic subtropical gyres. Mar Ecol Prog Ser 257:1-11

McGillicuddy DJ, Robinson AR, Siegel DA, Jannasch HW and 5 others (1998) Influence of mesoscale eddies of new production in the Sargasso Sea. Nature 394:263-266

McGillicuddy DJ, Anderson LA, Doney SC, Maltrud ME (2003) Eddy-driven sources and sinks of nutrients in the upper ocean: results from a 0.1 degree resolution model of the North Atlantic. Global Biochem Cycles 17(2):1035, doi: 10.1029/2002GB001987

McNeil JD, Jannasch HW, Dickey T, McGillicuddy D, Brzezinski M, Sakamoto CM (1999) New chemical, biooptical and physical observations of upper ocean response to the passage of a mesoscale eddy off Bermuda. J Geophys Res 104:15537-15548

Mouriño B (2002) Estructuras de mesoescala (montes submarinos, frentes oceánicos y giros ciclónicos) en el Atlántico NE subtropical: su importancia en el balance de carbono de la capa fótica. PhD thesis, Universidade de Vigo

Mouriño B, Fernández E, Serret P, Harbour D, Sinha B, Pingree RD (2001) Variability and seasonality of physical and biological fields at the Great Meteor Tablemount (Subtropical NE Atlantic). Oceanol Acta 24:167-185

Mouriño B, Fernández E, Escánez J, de Armas D, Giraud S, Sinha B, Pingree RD (2002) A subtropical oceanic ring of magnitude (STORM) in the Eastern North Atlantic: physical, chemical and biological properties. Deep-Sea Res II 49:4003-4021

Mouriño B, Fernández E, Etienne H, Hernández F, Giraud S (2003) Significance of cyclonic SubTropical Oceanic Rings of Magnitude (STORM) eddies for the carbon budget of the euphotic layer in the subtropical NE Atlantic. J Geophys Res 108(C12), 3383, doi: 10.1029/ 2003JC001884

Mouriño B, Fernández E, Alves M (2004) Thermohaline struc-

Editorial responsibility: Otto Kinne (Editor-in-Chief), Oldendorf/Luhe, Germany ture, ageostrophic vertical velocity fields and phytoplankton distribution and production in the North East Atlantic subtropical front. J Geophys Res 109, C04020, doi: 10.1029/2003JC001990

New AL, Jia Y, Coulibaly M, Dengg J (2001) On the role of the Azores Current in the ventilation of the North Atlantic Ocean. Prog Oceanogr 48:163-194

Oschlies A (2001) Model-derived estimates of new production: new results point towards lower values. Deep-Sea Res II 48:2173-2197

Pelaez J, McGowan JA (1986) Phytoplankton pigment patterns in the California Current as determined by satellite. Limnol Oceanogr 31:927-950

Pingree RD, Sinha B, New AL, Waddington I, Head RN, Nechvolodov LV (1996) Will deep subtropical ring 'STORM Physalia' cross the mid Atlantic Ridge and reach America? J Mar Biol Assoc UK 76:553-567

Pingree RD, Garcia-Soto C, Sinha B (1999) Position and structure of the Subtropical/Azores Front region from combined Lagrangian and remote sensing (IR/altimeter/SeaWiFS) measurements. J Mar Biol Assoc UK 79:769-792

Rogers AD (1994) The biology of seamounts. Adv Mar Biol 30:305-350

Serret P, Robinson C, Fernández E, Teira E, Tilstone G (2001) Latitudinal variation of the balance between plankton photosynthesis and respiration in the eastern Atlantic Ocean. Limnol Oceanogr 46:1642-1652

Serret P, Fernández E, Robinson C (2002) Biogeographic differences in the net ecosystem metabolism of the open ocean. Ecology 83:3225-3234

Siegel DA, McGillicuddy DJ, Fields EA (1999) Mesoscale eddies, satellite altimetry, and new production in the Sargasso Sea. J Geophys Res 104:13359-13379

Smith RD, Maltrud M, Bryan F, Hecht MW (2000) Numerical simulation of the North Atlantic Ocean at $1 / 10^{\circ}$. J Phys Oceanogr 30:1532-1561

Sweeney EN, McGillicuddy DJ, Buesseler KO (2003) Biogeochemical impacts due to mesoscale eddy activity in the Sargasso Sea as measured at the Bermuda Atlantic Time Series (BATS) site. Deep-Sea Res II 50:3017-3039

Teira E, Pazó MJ, Serret P, Fernández E (2001) Dissolved organic carbon production by microbial populations in the Atlantic Ocean. Limnol Oceanogr 46:1370-1377

Submitted: December 4, 2003; Accepted: July 27, 2004

Proofs received from author(s): February 4, 2005 